\title{
Scheduled Faecal Sludge Service (SFSS) for Sustainable Faecal Sludge Management in Cilacap
}

\author{
Agus Sudrajat ${ }^{*}$, Sudarno ${ }^{1}$, Yanuar Luqman ${ }^{2}$ \\ ${ }^{1}$ Master Program of Environmental Science, School of Postgraduate, Diponegoro University, Semarang \\ - Indonesia \\ ${ }^{2}$ Department Of Communications, Faculty of Social and Political Sciences, Diponegoro University, \\ Diponegoro University, Semarang - Indonesia
}

\begin{abstract}
In accordance with the 6'th Sustainable Development Goals (SDG's), that ensurin availability and sustainable management of water and sanitation for all and with the launch of the 100-0-100 movement by Indonesian Government, which is a program to achieve the $100 \%$ accesss for water, $0 \%$ for slums, and $100 \%$ accesss to proper sanitation, Cilacap government need to work harder to achieve $100 \%$ accesss to proper sanitation especially in faecal sludge management that still needs to be improved. More than 98\% households in Cilacap are using on-site sanitation system, without periodicaly emptied, and its causing problems in public health, and has impact for environmental and economic nearby communities. This study was held in Cilacap, a municipal in Central Java, Indonesia, using secondary data and literature review. This study aims to analyze feseability of the plan of implementation Scheduled Faecal Sludge Service (SFSS). Based on analysis, Cilacap are feasible to implementing SFSS as long as Cilacap could ensure to repair all gaps that shown in Gap analysis. Data of sludge service areas in cilacap, operating patterns, SFSS implementation procedures, and financial calculations must be made on preparation stage of SFSS.
\end{abstract}

Keywords : Faecal Sludge Management, Sanitation

\section{Introduction}

Most cities of developing countries in Asia and Africa still using on-site sanitation systems such as septic tanks or cesspools to treat their wastewaters [1]. Faecal sludge has highly pollute is often disposed on public land with or without permission of the landowners $[2,3]$

\footnotetext{
${ }^{*}$ Corresponding author: agussudrajat@students.undip.ac.id
} 
and its causing problems in public health, and has impact for environmental and economic nearby communities [4].

Cilacap is one of municipal in Cilacap regency in Central Java Province, Indonesia. It has 3 sub-districts and consist of 15 villages, with area $50,10 \mathrm{~km} 2$ and population on 2019 is about 257.334 [5]. Cilacap is a centre of government, business, education, health, and industrial. It makes Cilacap has the most population, and many housing rapidly growing every year. Sanitation accesss in Cilacap is not proper enough, for urban areas are more serviced than peripheral areas, this is very reasonable given that in urban areas there are more inhabitants and higher densities so the risk level is also higher [6]. More than 2.7 billion people in this world using onsite system (pit latrines, septic tanks and pour flush latrines) for their sanitation needs [1], and about 98\% households in Cilacap manage faecal sludge also using onsite system, without regular or periodic emptying [7]. Septic tanks or pit latrine is some of types of containments technologies for storing faecal sludge that produced by households [8], and now the Sustainable Development Goals (i.e., SDGs) have defined a new target to achieve accesss to adequate and equitable sanitation and hygiene for all and end open defecation by 2030 [9].

\section{Methodology}

This study are using secondary data, literature study method, and analyzing of SFSS. Literature study are taken from books, reports, and results of studies from journals in the period 2009- 2020 that related to the Faecal Sludge Management (FSM). This study are using secondary data, literature study method, and analyzing of SFSS. The results of this literature review will be use to analyze the right strategy for Cilacap in handling faecal sludge management especially study of feasibility of the plan of implementing Scheduled Fecal Sludge Service (SFSS).

\subsection{Existing Faecal Sludge Management in Cilacap}

More than $96 \%$ households in Cilacap using onsite system to manage their faecal sludge, without regular or periodic emptying, $72,31 \%$ uses permanent pit latrines, $15,72 \%$ uses semipermanent pit latrines, $10,07 \%$ uses sharing pit latrines, and about $1,90 \%$ still open defecation [7] (see table 1). 
Table 1. Progress of sanitation accesss in Cilacap 2020

\begin{tabular}{|l|l|l|l|l|l|l|}
\hline \multirow{2}{*}{\begin{tabular}{c}
\multirow{2}{*}{$\begin{array}{c}\text { Progress of Sanitation } \\
\text { Access }\end{array}$} \\
\cline { 2 - 7 }
\end{tabular}} & $\begin{array}{c}\text { Cilacap } \\
\text { Tengah }\end{array}$ & $\mathbf{( \% )}$ & $\begin{array}{c}\text { Cilacap } \\
\text { Utara }\end{array}$ & $\mathbf{( \% )}$ & $\begin{array}{l}\text { Cilacap } \\
\text { Selatan }\end{array}$ & $\mathbf{( \% )}$ \\
\hline Households & 20.482 & & 18.577 & & 27.687 & \\
Permanent Pit Latrine & 13.271 & 62,02 & 13.750 & 73,44 & 23.647 & 81,47 \\
Semi Permanent Pit Latrine & 4.368 & 20,47 & 3.017 & 15,13 & 2.551 & 11,56 \\
Sharing Pit Latrine & 2.406 & 14,39 & 1.803 & 11,40 & 1.003 & 4,40 \\
Open Defecation & 437 & 3,12 & 7 & 0,03 & 486 & 2,56 \\
Accumulative Progress (\%) & 96,88 & & 99,97 & & 97,44 & \\
\hline
\end{tabular}

On-Site sanitation system means the excreta will be storage in a containment where occupied by the dwelling and its immediate surroundings. It can be disposed of mechanically (by vacum truck) on site or disposal treatment plant or removed manually for safe disposal [10]. Many households will emptying their septic tanks if needed by faecal sludge emptying operators. The operator can be from Cilacap government or from faecal sludge emptying company/private sectors.

Good Managed sanitation is the final goal of all faecal sludge management (FSM) activity. The Sustainable Development Goals (SDG) defines: "Good sanitation is improving the facilities which are not shared with other households and where excreta are safely disposed in situ or transported and treated off-site [11].

Most FSM is not in a good managed with a lack of proper and safely emptying, illegal dumping directly in the environment and no sewage water treatment plants [9]. The government must ensure without discrimination that everyone has physical and economic accesss to sanitation, in all spheres of life, which is safe, hygienic, secure, socially and culturally acceptable, provides privacy and ensures dignity" [12]. Acknowledgement of the importance of faecal sludge management is rapidly increasing, as evidenced by inclusion in the sustainable development goals (SDGs) [13]. With adequate management of the entire service chain, faecal sludge management can provide sustainable sanitation and protection of public health [14].

\subsection{Scheduled Fecal Sludge Service (SFSS)}

Faecal sludge management (FSM) is a challenge of sanitation in many developing countries. They are moving towards increased sanitation coverage, the issue of safe handling of sludge has emerged as an important and challenging issue of concern [15]. Faecal Sludge Management (FSM) consist of five components, storage, collection, transport, treatment and safe enduse or disposal [16].

Faecal sludge must be remove periodically from the storage [17]. If faecal sludge not managed properly, these waste products can be cause of waterborne disease [9] and it is to minimize environmental pollution [4]. A service to remove periodically faecal sludge from septic tank is called a Scheduled Fecal Sludge Service (SFSS). SFSS is a sludge removal service in periodically as required by the municipal government with the specified 
descheduling schedule [17]. Desludging in SFSS was not carried out due to requests from households/septic tank users. Like it or not, necessary or unnecessary, desludging in SFSS will be carried out according to the schedule. Although it will certainly be determined by the local government, the SFSS desludging period generally ranges from 2-5 years [17].

\subsection{Analysis for plan of implementing Scheduled Fecal Sludge Service (SFSS)}

At the beginning of preparation period of implementing SFSS, gap analysis must be carried out by using secondary information. SFSS has 7 management aspects so that they can be well organized and sustainable. The 7 aspects must be developed in accordance with the characteristics and capabilities of the region, as well as of course with the service objectives to be achieved [17]. The 7 aspects are :

a. Pattern of operation

b. Customer

c. Infrastructure

d. Institutional

e. Procedure

f. Financial

g. Rules / regulation

Population and buildings, the level of use of the septic tank and the conditions, the existence and coverage of wastewater piping systems, the existence of fecal sludge services from the government and from fecal sludge services company, the number of trucks or other stools emptying units, the capacity and conditions of the sewage sludge treatment plant or waste water treatment plant, institutions related to waste water and sewage sludge management, regulations related to waste water and sewage sludge management are the important information that needs to be prioritized in implementing SFSS and to identified the feasibility of implementing SFSS in Cilacap, it can using gap analysis. Gap analysis is a comparing current conditions of the city (potential of the city) with conditions that required by SFSS [17].

The evaluation results from the information about current condition of the city will be the basis of judgment on whether a city is proper to immediately prepare SFSS. Maybe at the end of this work step, we conclude that SFSS is not feasible to be developed at this time in a city. For example, due to the low level of use of septic tanks or due to the absence of water waste treatment plant in the city. If the two conditions have been overcome then the city can be considered feasible to immediately prepare SFSS. A serious problem that can make SFSS unfeasible is the low level of use of septic tanks in a city, especially if we want SFSS to be financially independent. The small number of septic tank users will make the economies of scale of SFSS operations not enough to make it able to finance itself. In cities like this, the local government is better off optimizing the existence of on-call sludge services [17]

SFSS has never been implemented by Cilacap, and this study was conducted to analyze the feasibility of SFSS implementation plan in Cilacap with all supporting facilities such as waste water treatment plant, desludging vehicles, supporting facilities and buildings, regulations. For that we need to do an analysis that is by analyzing the data that has been obtained. 


\section{Discussion}

The success of FSM in any country need an availability of a system that could handling all aspects of FSM including safe faecal sludge emptying, transportation, treatment and disposal [18]. Developing solutions for FSM will be an ongoing need into the future, if we are to achieve solutions for global sanitation. Resource recovery based solutions for FSM provide a promising approach. However, technology based solutions by engineers will only succeed within an enabling environment framework [9]. An institutional framework needs tibe developed based on situation in Cilacap to achieve successful implementation of SFSS. It is depends on an effective management system [19].

Based on literature of SFSS [17] and from secondary data about Cilacap, it is obtained that Cilacap has potential data such as : 
Table 2. Potential data of Cilacap

\begin{tabular}{|c|c|}
\hline Informations & Current Condition \\
\hline $\begin{array}{l}\text { Data of service area of faecal sludge } \\
\text { management }\end{array}$ & $\begin{array}{l}\text { Cilacap has no data of service area of faecal } \\
\text { sludge management }\end{array}$ \\
\hline $\begin{array}{l}\text { Current conditions of the level of use of the } \\
\text { septic tank }\end{array}$ & $\begin{array}{l}\text { Cilacap has data of Current conditions of the } \\
\text { level of use of the septic tank [7] }\end{array}$ \\
\hline $\begin{array}{l}\text { The existence and coverage of wastewater } \\
\text { piping systems }\end{array}$ & $\begin{array}{l}\text { Cilacap has data of existence and coverage } \\
\text { of wastewater piping systems [6] v }\end{array}$ \\
\hline $\begin{array}{l}\text { Current conditions of faecal sludge services } \\
\text { from the government and from faecal sludge } \\
\text { services company }\end{array}$ & $\begin{array}{l}\text { Faecal sludge service in Cilacap are } \\
\text { currently carried out by Cilacap Government } \\
\text { and private sector. From the government, } \\
\text { faecal sludge service is carried out by } \\
\text { Department of Housing, Settlement, and } \\
\text { Land Areas of Cilacap, while from the } \\
\text { private sector, carried out by several } \\
\text { partners, Cilacap has } 8 \text { faecal sludge service } \\
\text { partners from private sectors. }\end{array}$ \\
\hline $\begin{array}{l}\text { Number of trucks or other emptying vehicle } \\
\text { units }\end{array}$ & $\begin{array}{l}\text { Cilacap currently has } 2 \text { units of Vacuum } \\
\text { truck, and } 1 \text { unit of vacuum motorcycle }\end{array}$ \\
\hline $\begin{array}{l}\text { Capacity and conditions of the sewage water } \\
\text { treatment plant }\end{array}$ & $\begin{array}{l}\text { Cilacap currently has a waste water } \\
\text { treatment plant, with conditions that require } \\
\text { maintenance because it cannot operate } \\
\text { optimally, although it is currently still being } \\
\text { used [6] }\end{array}$ \\
\hline $\begin{array}{l}\text { Institutions related to waste water and faecal } \\
\text { sludge management }\end{array}$ & $\begin{array}{l}\text { Fecal sludge management are managed by } \\
\text { the Department of Housing, Settlement and } \\
\text { Land of Cilacap[20] }\end{array}$ \\
\hline & $\begin{array}{l}\text { Cilacap government has issued several } \\
\text { regulations regarding the management of } \\
\text { sludge, namely: } \\
\text { a. Regulation no. } 152 \text { (2018) about Faecal } \\
\text { sludge management in Cilacap }\end{array}$ \\
\hline $\begin{array}{l}\text { Regulations related to waste water and faecal } \\
\text { sludge management }\end{array}$ & $\begin{array}{l}\text { b. Regulation No. } 149 \text { (2018) about } \\
\text { Achievment of performance target for } \\
\text { receiving retribution of emptying Septic } \\
\text { tank, grave, cremation, and use of wealth } \\
\text { of Cilacap in } 2018 \text { [21] } \\
\text { c. Regulation No. } 06 \text { (2012) about } \\
\text { Retribution of septic tank emptying [22] }\end{array}$ \\
\hline
\end{tabular}




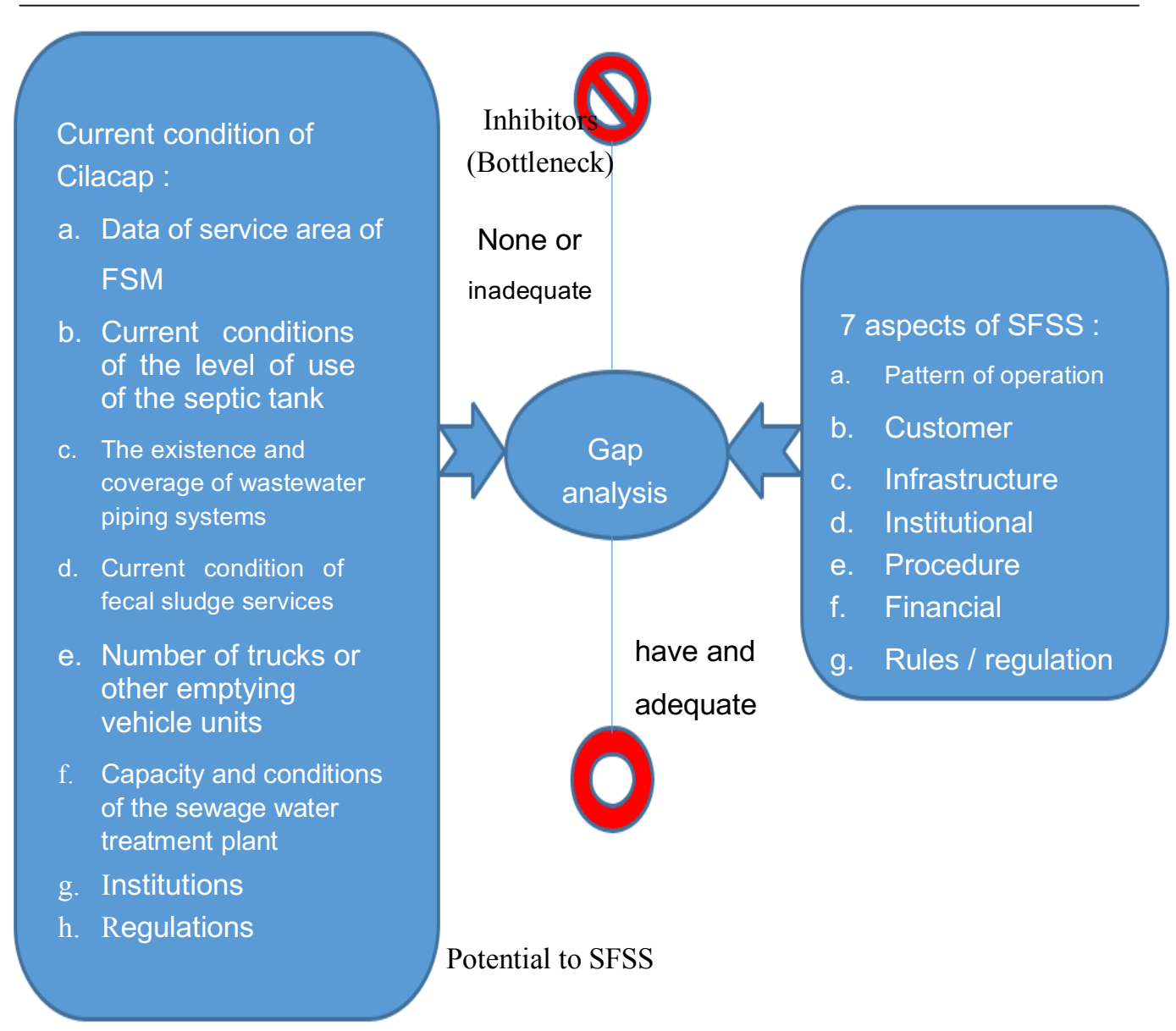

Fig. 1. Gap analysis of SFSS in Cilacap

From the data of current condition of Cilacap in accordance with the requirements of the city that will implement the SFSS program, it can be seen that Cilacap has the potential to implement the SFSS, this is obtained by Gap analysis, where current conditions are combined with 7 aspects of SFSS, it will be potential for implementing the SFSS. Although Cilacap does not yet have data on sludge service areas in cilacap, operating patterns, SFSS implementation procedures, and financial calculations, this data can be made during the preparation stage of the SFSS implementation and it is hoped that SFSS can be carried out sustainably. In other words, Cilacap is feseable to implement SFSS.

\section{Conclusion}

Based on result of Gap analysis Cilacap are feasible to implementing SFSS as long as Cilacap could ensure to repair all gaps that shown in Gap analysis. Data of sludge service areas in cilacap, operating patterns, SFSS implementation procedures, and financial calculations must be made on preparation stage of SFSS. In addition, permission from the government and community participation must also be included in this peparation stage so that all parties can give constructive opinions to the implementation of a sustainable SFSS. 


\section{References}

[1] IWA Publishing, Faecal Sludge Management - System Approach for Implementation and Operation. london: IWA Publishing. (2014)

[2] USAID/EAWAG, “A Rapid Assesment Septage Management in Asia : Policies and Pratice in India, Indonesia, Malaysia the Philippines, Sri Lanka, Thailand, and Vietnam," no. December 2015, (2010)

[3] UNICEF / WHO, Progress on Drinking Water and Sanitation 2012 Update. (2012)

[4] A. Taweesan, T. Koottatep, and C. Polprasert, "Effective Faecal Sludge Management Measures for on-site sanitation systems," Researchgate, no. September, (2015)

[5] BPS Kab. Cilacap, Kabupaten Cilacap Dalam Angka 2020. Cilacap: BPS Kab. Cilacap, (2020)

[6] Kabupaten Cilacap, “Strategi Sanitasi Kabupaten Cilacap 2016-2020,” Cilacap, (2016)

[7] Dinas kesehatan Kab. Cilacap, “Data ODF Kab. Cilacap 2020,” Cilacap, (2020)

[8] M. Englund, J. Pablo, V. Nguyen, and L. Strande, "Modelling quantities and qualities ( $Q \& Q$ ) of faecal sludge in Hanoi, Vietnam and Kampala, Uganda for improved management solutions," ELSEVIER, vol. 261, (2020)

[9] H. Harada and L. Strande, "Challenges and Opportunities of Faecal Sludge Management for Global Sanitation," Researchgate, no. May 2019, (2016)

[10] D. K. M. Mbeguere, J.B. Gning, P.H. Dodane, "Socio-economic profile and profitability of faecal sludge emptying companies," ELSEVIER, pp. 1288-1295, (2010)

[11] S. D. Shrestha, "Status of Municipal Faecal Sludge Management Planning in the New Constitutional Arrangement of Nepal Status of Municipal Faecal Sludge Management Planning in the New Constitutional Arrangement of Nepal," Researchgate, no. February 2019, (2020)

[12] UN Water, “UN-Water Annual Report 2009," United natons, pp. 1-22, (2009)

[13] UNICEF / WHO, Progress on Drinking Water and Sanitation 2014 Update. (2014)

[14] P. Dodane, O. Sow, and L. Strande, "Capital and Operating Costs of Full-Scale Fecal Sludge Management and Wastewater Treatment Systems in Dakar, Senegal," Environ. Sci. Technol., 2012. 
[15] N. Bari, "STUDY ON EXISTING FAECAL SLUDGE MANAGEMENT SITUATION IN RAJSHAHI RAJSHAHI CITY," Researchgate, no. March, (2017)

[16] M. Hasan, A. U. Husna, A. Rahman, and A. Alam, "Community faecal sludge management strategy among urban slum people of Khulna city-Bangladesh," Researchgate, no. January, (2019)

[17] USAID, SAATNYA SEKARANG ! - Layanan lumpur tinja terjadwal. Jakarta: USAID, (2016)

[18] I. N. J M Tembo, E Nyirenda, "Enhancing faecal sludge management in periurban areas of Lusaka through faecal sludge valorisation: challenges and opportunities,"

IOP Sci., (2016)

[19] M. Bassan, "Institutional Frameworks for Faecal Sludge Management," Faecal Sludge Manag. - Syst. approach Implement. Oper., no. April, pp. 255-272, (2014)

[20] Pemerintah Kab. Cilacap, Peraturan Bupati Cilacap No. 152 tahun 2018. Indonesia, pp. 1-6 (2018)

[21] Pemerintah Kab. Cilacap, Peraturan Bupati Cilacap No. 149 tahun 2018., pp. 1-5. (2018)

[22] Pemerintah Kab. Cilacap, PERDA Kabupaten Cilacap No. 6 tahun 2002. Indonesia, (2012) 